\title{
The diploporite blastozoan Lepidocalix pulcher from the Middle Ordovician of northern Algeria: Taxonomic revision and palaeoecological implications
}

Yamouna Makhlouf, Bertrand Lefebvre, Elise Nardin, Ahmed Nedjari, and Christopher R.C. Paul Acta Palaeontologica Polonica 62 (2), 2017: 299-310 doi:https://doi.org/10.4202/app.00286.2016

We present revision of the taxonomy and palaeoecology of the Ordovician aristocystitid Lepidocalix pulcher from the Zaouïa of Stita (Great Kabylia, Algeria). An emended diagnosis is proposed, highlighting the four-fold ambulacral system and the typical thecal plating organised in circlets. Lepidocalix is here assigned to the subfamily Calicinae of the family Aristocystitidae. The latex casts show fitted sutures between plates, slightly abraded spines, and well-preserved oral surface. The thecal plates possess up to three dipores, each, included into the spines. The presence of such covered diplopores would have reduced the respiration rate, by restricting their exchange surface area. The spines covering the dipores are not articulated and they could have a protective role. Lepidocalix is interpreted as stationary epifauna, probably using iceberg strategy to be stabilized into the soft substrate.

Key words: Echinodermata, Diploporita, taxonomy, palaeoecology, Ordovician, Algeria, Stita.

Yamouna Makhlouf [yamouna.makhlouf@gmail.com],Université Frères Mentouri Constantine, FSTGAT, Campus Zouaghi Slimane, Route Aïn el Bey, 25000 Constantine, Algérie-Laboratoire Géodynamique des Bassins Sédimentaires et des Orogènes (LGBSO), Université des Sciences et de la Technologie Houari Boumediene, FSTGAT, BP 32, El Alia, Bab Ezzouar, 16000 Alger, Algeria. Bertrand Lefebvre [bertrand.lefebvre@univ-lyon1.fr], UMR CNRS 5276 LGLTPE, Université Lyon 1, bâtiment Géode, 2 rue Raphaël Dubois, 69622 Villeurbanne, France. Elise Nardin [elise.nardin@get.omp.eu], Géosciences Environnement Toulouse, Observatoire Midi-Pyrénées, CNRS, IRD, Université de Toulouse, 14 avenue Edouard Belin, 31400 Toulouse, France. Ahmed Nedjari [nedjaria@gmail.com ], Laboratoire Géodynamique des Bassins Sédimentaires et des Orogènes (LGBSO), Université des Sciences et de la Technologie Houari Boumediene, FSTGAT, BP 32, El Alia, Bab Ezzouar, 16000 Alger, Algeria. Christopher R.C. Paul [glcrcp@bristol.ac.uk], The Beeches, Rhode Lane, Uplyme, Lyme Regis, Dorset, DT7 3TU, UK. 
This is an open-access article distributed under the terms of the Creative Commons

Attribution License (for details please see creativecommons.org), which permits unrestricted use, distribution, and reproduction in any medium, provided the original author and source are credited.

FarF Full text $(1,104.1 \mathrm{kB})$ 